\title{
POTENSI EKONOMI DAN ARAHAN PENGEMBANGAN PEREKONOMIAN WILAYAH DI DESA-DESA PENYANGGA TAMAN NASIONAL UJUNG KULON
}

\section{Economic Potential and Direction of Economic Development in the Region of The Village Buffer at Ujung Kulon National Park}

\author{
Tb Iwan Mulyawan ${ }^{1}{ }^{*}$, Baba Barus ${ }^{2)}$, dan Muhamad Firdaus ${ }^{3)}$ \\ 1) Alumni Program Studi Ilmu Perencanaan Wilayah, Sekolah Pascasarjana IPB, Jl. Raya Darmaga, Gedung Andi \\ Hakim Nasoetion Kampus IPB Darmaga Bogor 16680 \\ 2) Departemen Ilmu Tanah dan Sumberdaya Lahan, Fakultas Pertanian IPB, J1. Meranti Kampus IPB Darmaga \\ Bogor 16680 \\ 3) Departemen Ekonomi, Fakultas Ekonomi dan Manajemen IPB, Jl. Kamper Kampus IPB Darmaga Bogor 16680
}

\begin{abstract}
Sumur District and Cimanggu District are the buffer areas of Ujung Kulon National Park (UKNP). Based on the Spatial Planning of Pandeglang Regency 2013, the districts were designated as the center development of trade and services. In fact there are still lack of infrastructure. This condition is the main problem of regional development plan. This study aims to: (1) analyze of the village hierarchy based on areas for Sumur District and Cimanggu District; (2) analyze the main sector that support the regional development; (3) propose the economic development programs in Sumur District and Cimanggu District. The results shows that are twelve (12) UKNP buffer villages in hierarchy III. In hierarchy III, where there are five villages that have a relatively high economically disadvantaged population $(79.9 \%-87.8 \%)$. There are six villages in hierarchy II, and only one village in hierarchy I. The main sector in Sumur District, are rice (wet cultivation), vegetables, ornamental plants, livestock, fisheries and tourism. The main commodities in Cimanggu District, are rice, crops, vegetables, livestock and plantations. The recommendation of regional development in Sumur District are fishery and tourism, the program of modern fishing technology, construction of ports and financial/capital institutions, facilities and infrastructure for tourism. The recommendation of regional development in Cimanggu District is on agriculture and plantation, the program of agricultural technology, financial/capital institutions, facilities and infrastructure to support local economy.
\end{abstract}

Keywords: Area development, area hierarchy, pandeglang, potential of buffer areas in TNUK

\begin{abstract}
ABSTRAK
Kecamatan Sumur dan Kecamatan Cimanggu merupakan wilayah penyangga Taman Nasional Ujung Kulon (TNUK). Berdasarkan RTRW Kabupaten Pandeglang 2013, kedua wilayah tersebut diperuntukkan sebagai pusat pengembangan perdagangan dan jasa. Pada kenyataannya masih terkendala dengan keterbatasan infrastruktur. Kondisi ini menjadi permasalahan utama dari rencana pengembangan wilayah yang telah ditetapkan. Penelitian ini bertujuan: (1) Menganalisis hierarki wilayah berdasarkan aksesibilitas dan jumlah fasilitas per desa; (2) Menganalisis sektor unggulan yang mendukung pengembangan wilayah; (3) Menyusun arahan program pengembangan perekonomian di Kecamatan Sumur dan Kecamatan Cimanggu. Hasil penelitian menunjukkan bahwa analisis skalogram mengindikasikan beberapa desa penyangga TNUK, yaitu terdapat dua belas yang termasuk hierarki III. Dari desa-desa yang termasuk hierarki III terdapat lima desa yang memiliki penduduk prasejahtera tinggi $(79.9 \%$ - 87.8\%). Selanjutnya terdapat enam desa yang termasuk hierarki II, sedangkan satu desa berada pada Hierarki I. Sektor unggulan di Kecamatan Sumur adalah pertanian, peternakan, perikanan dan pariwisata. Sektor unggulan di Kecamatan Cimanggu adalah pertanian, peternakan, dan perkebunan. Adapun arahan pengembangan wilayah di Kecamatan Sumur adalah perikanan dan pariwisata, program penerapan teknologi perikanan, pembangunan pelabuhan/darmaga, pembangunan kantor lembaga keuangan, sarana, dan prasarana wisata, sedangkan arahan pengembangan di Kecamatan Cimanggu adalah pertanian dan perkebunan, program penerapan teknologi pertanian.
\end{abstract}

Kata kunci: Pengembangan wilayah, hierarki wilayah, Pandeglang, potensi wilayah penyangga TNUK

\section{PENDAHULUAN}

Pengembangan wilayah Kecamatan Sumur dan Cimanggu Kabupaten Pandeglang tidak terlepas dari keberadaan Taman Nasional Ujung Kulon (TNUK) yang merupakan wilayah konservasi sumberdaya alam (SDA). Kebijakan pengembangan wilayah Taman Nasional Ujung
Kulon merupakan bagian dari strategi kebijakan pembangunan yang terkait dengan pemeliharaan dan perwujudan kelestarian lingkungan hidup, dimana TNUK sebagai kawasan konservasi berupaya mempertahankan fungsi ekologis dan ekosistemnya untuk mendukung peningkatan kesejahteraan masyarakat dan mutu kehidupan masyarakat. Keberadaan desa-desa di sekitar 
TNUK merupakan wilayah yang menjadi sasaran kebijakan pembangunan di Kabupaten Pandeglang yang berpengaruh terhadap aspek sosial ekonomi masyarakat. Implikasi langsung dari keberadaan TNUK adalah terbukanya akses wilayah, baik akses masuk maupun akses keluar wilayah setempat.

Pengembangan wilayah dapat dilihat pada potensi ekonomi wilayah dan sumberdaya alam yang ada (Regameya dan Kytzia, 2007) serta ketergantungan masyarakat terhadap sumberdaya alam yang masih cukup tinggi (Niu et al., 2012). Kawasan TNUK merupakan sumber penghidupan bagi masyarakat di sekitarnya baik secara ekonomi maupun secara sosial. Tinggi rendahnya interaksi masyarakat terhadap kawasan tentunya dipengaruhi oleh banyak faktor salah satunya adalah tingkat kesejahteraan masyarakat. Berdasarkan data kesejahteraan masyarakat desa penyangga, 64.9\% dari masyarakat Sumur tergolong keluarga pra-sejahtera dan sejahtera 1, sedangkan masyarakat di Kecamatan Cimanggu $61.4 \%$ tergolong keluarga pra-sejahtera dan sejahtera 1 . Hal itu menunjukkan bahwa hampir sebagian besar masyarakat desa di Kecamatan Sumur dan Kecamatan Cimanggu masih memiliki tingkat kesejahteraan yang rendah.

Di masa kini, pemerintah daerah membuat perencanaan pengembangan wilayah Kecamatan Sumur dan Cimanggu sebagai wilayah pusat pengembangan perdagangan dan jasa, khususnya di bidang pariwisata. Namun pengembangan kedua sektor ini masih terkendala karena keterbatasan infrastruktur. Penelitian ini bertujuan: (1) Mengetahui hierarki wilayah desa di Kecamatan Sumur dan Kecamatan Cimanggu; (2) Mengetahui sektor unggulan yang mendukung pengembangan wilayah di Kecamatan Sumur dan Kecamatan Cimanggu serta (3) Menyusun arahan program pengembangan perekonomian di Kecamatan Sumur dan Kecamatan Cimanggu.

\section{BAHAN DAN METODE}

Lokasi penelitian adalah di Kecamatan Sumur dan Kecamatan Cimanggu. Data yang digunakan dalam penelitian ini adalah data primer dan data sekunder. Data primer diperoleh melalui wawancara dan pengisian kuesioner. Adapun Stakeholder yang terlibat menjadi responden antara lain adalah Balai Taman Nasional Ujung Kulon, Camat Kecamatan Sumur, Camat Kecamatan Cimanggu, dan tokoh masyarakat, UPT PPI/TPI manajer Kecamatan Sumur, Manajer TPI Tamanjaya, dan dosen Universitas Sultan Ageng Tirtayasa. Data sekunder bersumber dari Badan Pusat Statistik (BPS) Kabupaten Pandeglang, Balai Taman Nasional Ujung Kulon (TNUK), dan instansi lainnya yang terkait.

Peralatan yang digunakan anatara lain: komputer, kamera digital dan alat tulis. Komputer yang digunakan dalam penelitian ini dilengkapi dengan software Ms word, Excell, dan ArcGIS versi 9.3.
Penelitian ini menggunakan 4 (empat) metode analisis data yaitu:

1. Analisis Skalogram untuk menganalisis hierarki pusatpusat pelayanan berdasarkan ketersediaan infrastruktur dan fasilitas pelayanan yang dimiliki. Variabel yang digunakan adalah jarak pusat pelayanan, jumlah jenis dan unit fasilitas serta kualitas pelayanan.

2. Analisis Location Quetient $(L Q)$

Analisis LQ merupakan suatu indeks untuk membandingkan pangsa sub wilayah dalam aktivitas tertentu dengan pangsa aktivitas tersebut dalam wilayah secara agregat (Panuju dan Rustiadi, 2011) yang dipakai untuk melihat sektor basis.

3. Analisis shift share digunakan untuk mengetahui tingkat pengembangan dan pergeseran ekonomi wilayah, kecenderungan transformasi struktur perekonomian wilayah, sumbangan suatu sektor terhadap perekonomian wilayah yang lebih luas dimana desa atau kelurahan terhadap kota, dan sektorsektor yang mengalami kemajuan selama periode pengukuran.

4. Analisis matriks SWOT bertujuan untuk mengidentifikasi alternatif-alternatif strategi yang layak dan sesuai untuk dilaksanakan. Dalam analisis ini perlu dilakukan identifikasi terhadap faktor-faktor internal dan eksternal dengan menggunakan matriks IFAS dan EFAS. Faktor-faktor ini digunakan untuk penentuan analisis SWOT yang dilakukan setelah mengetahui kekuatan, kelemahan, peluang dan ancaman (Rangkuti, 2009).

\section{HASIL DAN PEMBAHASAN}

\section{Tingkat Perkembangan Wilayah Desa di Kecamatan Sumur dan Kecamatan Cimanggu}

\section{Tipologi Wilayah Desa Menurut Analisis Skalogram}

Analisis Skalogram dilakukan untuk melihat hierarki wilayah berdasarkan ketersediaan infrastruktur, dan fasilitas pelayanan yang dimiliki. Hasil analisis skalogram menunjukkan bahwa tingkat pengembangan desa dikelompokkan ke dalam tiga hierarki wilayah (Tabel 1):

1. Hierarki I, merupakan wilayah dengan tingkat perkembangan maju. Wilayah ini dicirikan oleh indeks perkembangan desa paling tinggi yang ditentukan oleh jumlah ketersediaan sarana dan prasarana yang cukup memadai.

2. Hierarki II, termasuk wilayah dengan tingkat perkembangan sedang yang ditunjukkan oleh tingkat sarana dan prasarana yang tersedia di wilayah tersebut lebih sedikit dari hierarki I dan jarak masing-masing wilayah terhadap pusat-pusat pelayanan lebih jauh dari hierarki I.

3. Hierarki III, termasuk wilayah dengan tingkat perkembangan rendah yang ditunjukkan oleh tingkat sarana prasarana yang tersedia relatif sangat kurang dan jarak masing-masing wilayah terhadap pusat-pusat pelayanan relatif lebih jauh. 
Tabel 1. Indek Perkembangan Desa (IPD) di Kecamatan Sumur dan Kecamatan Cimanggu

\begin{tabular}{cccc}
\hline No & Kecamatan Sumur & IPD & Hierarki \\
\hline 1 & Kertajaya & 68.22 & 1 \\
2 & Sumberjaya & 58.90 & 2 \\
3 & Cigorondong & 42.30 & 2 \\
4 & Kertamukti & 36.24 & 3 \\
5 & Tamanjaya & 35.46 & 3 \\
6 & Tunggaljaya & 34.29 & 3 \\
7 & Ujungjaya & 25.62 & 3 \\
\hline No & Kecamatan & IPD & Hierarki \\
& Cimangu & & \\
\hline 1 & Tugu & 45.00 & 2 \\
2 & Waringinkurung & 43.25 & 2 \\
3 & Padasuka & 38.45 & 2 \\
4 & Cimanggu & 37.58 & 2 \\
5 & Cijaralang & 37.21 & 3 \\
6 & Mangkualam & 36.14 & 3 \\
7 & Cibadak & 35.56 & 3 \\
8 & Rancapinang & 31.59 & 3 \\
9 & Batuhideung & 28.13 & 3 \\
10 & Kramatjaya & 27.86 & 3 \\
11 & Ciburial & 27.07 & 3 \\
12 & Tangkilsari & 22.39 & 3 \\
\hline
\end{tabular}

Tabel 1 menunjukkan bahwa dari 19 desa di Kecamatan Sumur dan Cimanggu, hanya satu desa yang termasuk ke dalam hierarki 1 yaitu Desa Kertajaya Kecamatan Sumur. Desa Kertajaya memiliki infrastruktur, sarana, dan prasarana yang lebih lengkap daripada desadesa lainnya karena desa ini sebelumnya menjadi ibukota
Kecamatan Sumur. Selanjutnya terdapat 6 desa dengan hierarki 2, yaitu dua desa di Kecamatan Sumur dan empat desa di Kecamatan Cimanggu. Desa Sumberjaya termasuk dalam kategori hierarki 2 walaupun menjadi ibukota Kecamatan Sumur, hal ini dikarenakan sarana dan prasarana yang dimiliki lebih sedikit dibandingkan dengan Desa Kertajaya yang dikategorikan sebagai desa hierarki 1. Berikutnya terdapat 12 desa dengan kategori hierarki 3, yaitu empat desa berada di Kecamatan Sumur dan delapan desa di Kecamatan Cimanggu. Kecamatan Cimanggu memiliki desa-desa dengan hierarki lebih rendah lebih banyak dibandingkan dengan Kecamatan Sumur. Dari 12 desa di Kecamatan Cimanggu, 8 desa termasuk desa dengan hierarki III, dan hanya 6 desa yang termasuk ke dalam hierarki II.

Gambar 1 berikut menunjukkan persebaran hierarki desa di Kecamatan Sumur dan Kecamatan Cimanggu. Keberadaan desa-desa di Kecamatan Sumur yang merupakan daerah pesisir, menjadikan pembangunan infrastruktur lebih terkonsentrasi di wilayah pesisir, walaupun Kecamatan Cimanggu lebih dekat posisinya dengan pusat kota Kabupaten Pandeglang. Kondisi ini juga menggambarkan bahwa ada kecenderungan pemusatan pembangunan infrastruktur desa-desa penyangga TNUK justru terletak di wilayah pesisir (desa-desa pesisir). Pemusatan pembangunan infrastruktur di wilayah pesisir juga ditunjukkan oleh peringkat Desa Kertajaya sebagai desa hierarki I.

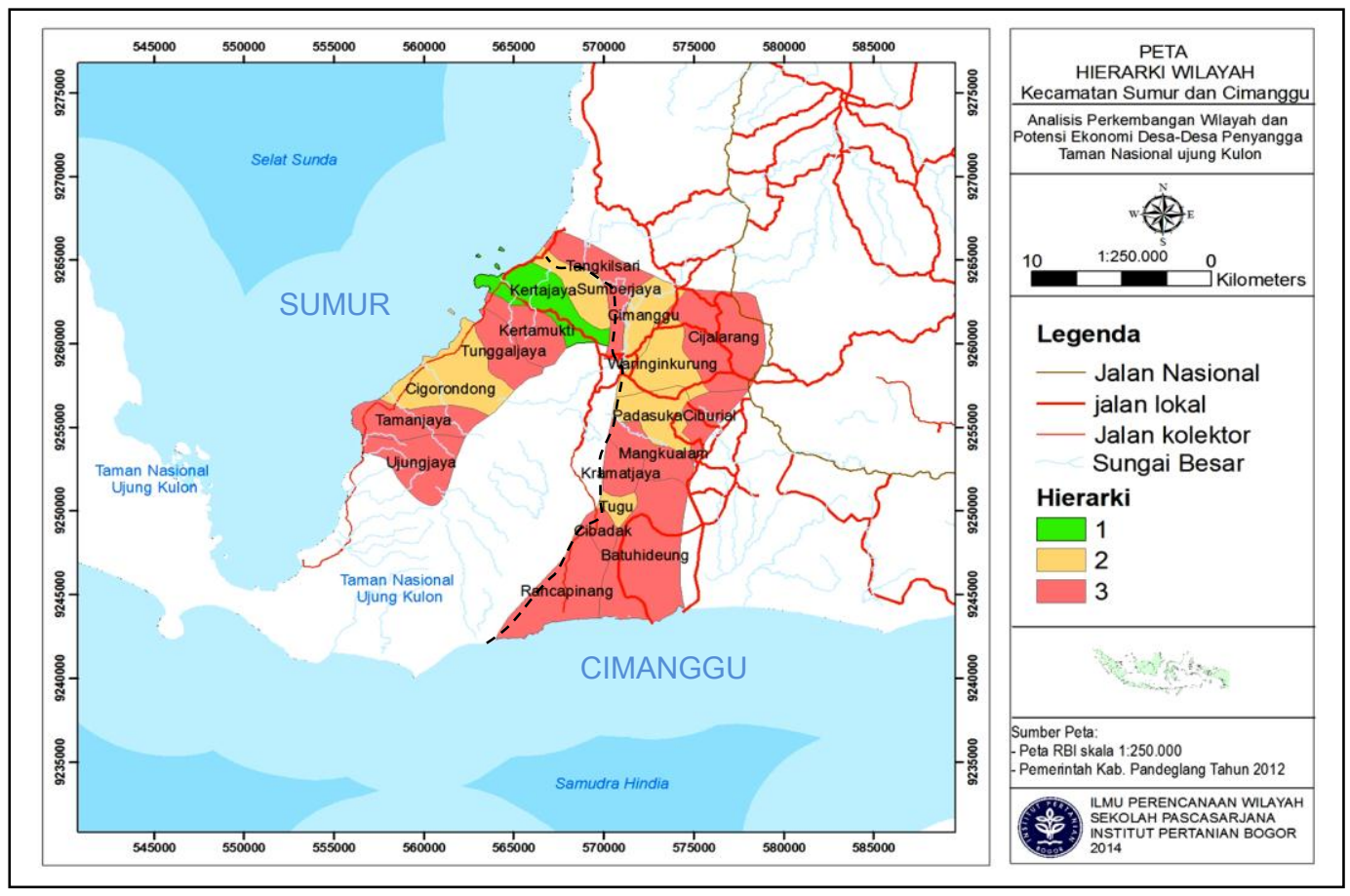

Gambar 1. Peta hierarki pengembangan wilayah/desa-desa penyangga TNUK

\section{Potensi Wilayah Kecamatan Penyangga Taman Nasional Ujung Kulon}

Kecamatan Sumur dan Kecamatan Cimanggu memiliki sumberdaya pada sektor-sektor pertanian, perkebunan, peternakan, perikanan, dan pariwisata. Sektor unggulan di kedua kecamatan ini dianalisis melalui analisis LQ dan SSA. Analisis ini menggunakan data produksi per kecamatan menurut lapangan usaha seperti tertera pada Tabel 2.

Berdasarkan analisis LQ sektor basis Kecamatan Sumur adalah pertanian, peternakan, dengan sektor andalan yaitu: perikanan dan pariwisata yang memusat di semua desa. Sektor andalan yang dikhususkan adalah perikanan tangkap tradisional di wilayah pesisir Ujung Kulon. Adapun untuk Kecamatan Cimanggu menunjukkan 
pemusatan pada sektor-sektor pertanian, peternakan, dan perkebunan.

Tabel 3 menyajikan nilai Shift Share Analysis untuk mengetahui keunggulan kompetitif dari kedua kecamatan dibandingkan dengan Kabupaten Pandeglang. Dari data produksi menunjukkan bahwa sektor pertanian, peternakan, perikanan, dan pariwisata memiliki keunggulan kompetitif di Kecamatan Sumur. Situasi berbeda dengan Kecamatan Cimanggu, dimana sektor yang kompetitif adalah pertanian, perkebunan, dan peternakan.

Tabel 2. Nilai LQ desa-desa Kecamatan Sumur dan Cimanggu Kabupaten Pandeglang

\begin{tabular}{clccccc}
\hline No & KEC. SUMUR & Pertanian & Perkebunan & Peternakan & Perikanan & Pariwisata \\
\hline 1 & Ujungjaya & 1.03 & 0.34 & 1.65 & 1.04 & 1.07 \\
2 & Tamanjaya & 0.49 & 0.32 & 2.08 & 3.04 & 2.29 \\
3 & Cigorondong & 0.88 & 0.28 & 1.26 & 1.88 & 2.56 \\
4 & Tunggaljaya & 0.88 & 0.19 & 1.61 & 1.79 & 1.39 \\
5 & Kertamukti & 1.01 & 0.34 & 0.29 & 1.81 & 1.40 \\
6 & Kertajaya & 0.63 & 0.21 & 0.45 & 3.38 & 4.44 \\
7 & Sumberjaya & 0.22 & 0.31 & 0.00 & 5.21 & 4.60 \\
\hline & KEC. CIMANGGU & & & & & \\
\hline 8 & Rancapinang & 1.31 & 1.15 & 0.25 & 0.00 & 0.43 \\
9 & Cibadak & 1.25 & 1.36 & 0.39 & 0.00 & 0.00 \\
10 & Batuhideung & 1.12 & 1.26 & 1.64 & 0.00 & 0.00 \\
11 & Tugu & 0.82 & 2.01 & 2.95 & 0.00 & 0.00 \\
12 & Kramatjaya & 1.20 & 1.72 & 0.31 & 0.00 & 0.00 \\
13 & Mangkualam & 1.28 & 1.20 & 0.40 & 0.00 & 0.00 \\
14 & Padasuka & 1.00 & 1.57 & 2.13 & 0.00 & 0.00 \\
15 & Ciburial & 1.13 & 2.01 & 0.46 & 0.00 & 0.00 \\
16 & Waringinkurung & 1.02 & 1.65 & 1.81 & 0.00 & 0.00 \\
17 & Cijaralang & 1.27 & 1.37 & 0.28 & 0.00 & 0.00 \\
18 & Cimanggu & 1.24 & 1.40 & 0.36 & 0.03 & 0.00 \\
19 & Tangkilsari & 1.01 & 2.63 & 0.46 & 0.00 & 0.00 \\
\hline & & & & & &
\end{tabular}

Tabel 3. Nilai Shift Share subsektor produksi di Kecamatan Sumur

\begin{tabular}{|c|c|c|c|c|c|c|c|c|}
\hline \multirow[t]{2}{*}{ No } & \multirow{2}{*}{$\begin{array}{c}\text { Wilayah/Sektor } \\
\text { Produksi }\end{array}$} & \multicolumn{2}{|c|}{ Sumur (Rp) } & \multicolumn{2}{|c|}{ Pandeglang (Rp) } & \multirow[t]{2}{*}{$\begin{array}{l}\text { Regional } \\
\text { Share }\end{array}$} & \multirow[t]{2}{*}{$\begin{array}{l}\text { Proportional } \\
\text { Shift }\end{array}$} & \multirow[t]{2}{*}{$\begin{array}{l}\text { Differential } \\
\text { Shift }\end{array}$} \\
\hline & & 2007 & 2012 & 2007 & 2013 & & & \\
\hline 1 & Pertanian & $24,766,460$ & $22,141,641$ & $1,392,439,000.71$ & $932,198,000.63$ & -0.22 & -0.11 & 0.22 \\
\hline 2 & Perkebunan & $1,312,070$ & $1,312,070$ & $271,187,000.18$ & $271,903,000.52$ & -0.22 & 0.23 & 0.00 \\
\hline 3 & Peternakan & $4,519,756$ & $4,140,948$ & $115,380,000.25$ & $95,739,000.81$ & -0.22 & 0.05 & 0.09 \\
\hline 4 & Perikanan & $5,913,480$ & $15,965,563$ & $189,806,000.79$ & $202,398,000.36$ & -0.22 & 0.29 & 1.63 \\
\hline 5 & Pariwisata & 5,986 & 19,119 & $1,438,214,000.25$ & $1,142,838,000.25$ & -0.22 & 0.02 & 2.40 \\
\hline
\end{tabular}

Tabel 4. Nilai Shift Share subsektor produksi di Kecamatan Cimanggu

\begin{tabular}{|c|c|c|c|c|c|c|c|c|}
\hline \multirow[t]{2}{*}{ No } & \multirow{2}{*}{$\begin{array}{l}\text { Wilayah/Sektor } \\
\text { Produksi }\end{array}$} & \multicolumn{2}{|c|}{ Cimanggu (Rp) } & \multicolumn{2}{|c|}{ Pandeglang (Rp) } & \multirow{2}{*}{$\begin{array}{l}\text { Regional } \\
\text { Share }\end{array}$} & \multirow{2}{*}{$\begin{array}{c}\text { Proportional } \\
\text { Shift }\end{array}$} & \multirow{2}{*}{$\begin{array}{c}\text { Differential } \\
\text { Shift }\end{array}$} \\
\hline & & 2007 & 2012 & 2007 & 2013 & & & \\
\hline 1 & Pertanian & $33,513,482$ & $43,403,482$ & $1,392,439,000.71$ & $932,198,000.63$ & -0.22 & -0.11 & 0.63 \\
\hline 2 & Perkebunan & $9,184,490$ & $10,550,260$ & $271,187,000.18$ & $271,903,000.52$ & -0.22 & 0.23 & 0.15 \\
\hline 3 & Peternakan & $4,214,165$ & $3,974,100$ & $115,380,000.25$ & $95,739,000.81$ & -0.22 & 0.05 & 0.11 \\
\hline 4 & Perikanan & 34,865 & 23,243 & $189,806,000.79$ & $202,398,000.36$ & -0.22 & 0.29 & -0.40 \\
\hline 5 & Pariwisata & 47,937 & 38,000 & $1,438,214,000.25$ & $1,142,838,000.25$ & -0.22 & 0.02 & 0.00 \\
\hline
\end{tabular}




\section{Tingkat Pengembangan Wilayah dan Sektor Unggulan}

Berdasarkan analisis antara jumlah masyarakat prasejahtera, pengembangan wilayah dan sektor/komoditas unggulan (Tabel 5), selanjutnya dapat diketahui beberapa gambaran spesifik dari kedua kecamatan tersebut.

Di Kecamatan Sumur, desa-desa yang memiliki jumlah penduduk miskin yang relatif besar adalah Desa Ujungjaya (87.8\%), Desa Cigorondong (85.6\%) dan Desa Tamanjaya (80.4\%). Kondisi ini terkait erat dengan ketersediaan infrastruktur yang masih kurang. Adapun sektor unggulan Desa Ujungjaya adalah pertanian, peternakan, perikanan dan pariwisata, sedangkan di desa Cigorondong, dan Tamanjaya adalah peternakan, perikanan dan pariwisata. Untuk di Kecamatan Cimanggu terdapat tiga desa yang memiliki penduduk pra sejahtera relatif tinggi yaitu terdapat di Desa Rancapinang (84.4\%), Desa Cijaralang (80.7\%) dan Desa Kramatjaya (79.9\%). kondisi ini didukung oleh adanya infrastruktur yang kurang. Adapun sektor unggulan di tiga desa tersebut adalah pertanian dan perkebunan.

Di Kecamatan Sumur, Desa Tamanjaya dan Desa Ujungjaya merupakan dua desa yang terletak di wilayah ujung barat dari pusat Kecamatan Sumur, sehingga jarak antara desa ini dengan pusat-pusat pelayanan yang berada di ibukota kecamatan relatif jauh. Kondisi ini diperparah dengan ketersediaan prasarana jalan yang belum layak untuk mencapai wilayah tersebut. Situasi ini tidak jauh berbeda kondisinya dengan Kecamatan Cimanggu. Desadesa yang memiliki penduduk prasejahtera yang relatif besar umumnya berada pada posisi wilayah yang jauh dari pusat Kecamatan Cimanggu, seperti Desa Rancapinang. Desa ini merupakan desa dengan posisi di ujung selatan di wilayah Kecamatan Cimanggu.

Tabel 5. Klasifikasi kesejahteraan, pengembangan wilayah dan sektor unggulan desa-desa Kecamatan Sumur dan Cimanggu

\begin{tabular}{|c|c|c|c|c|}
\hline No & Kecamatan Sumur & Hierarki & Pra KS \% & Sektor Unggulan \\
\hline 1 & Kertajaya & 1 & 54.1 & Perikanan, Pariwisata, \\
\hline 2 & Sumberjaya & 2 & 47.1 & Perikanan, Pariwisata \\
\hline 3 & Cigorondong & 2 & 85.6 & Perikanan, Pariwisata, Peternakan \\
\hline 4 & Tamanjaya & 3 & 80.4 & Perikanan, Pariwisata, Peternakan \\
\hline 5 & Tunggaljaya & 3 & 59.4 & Perikanan, Pariwisata, Peternakan \\
\hline 6 & Kertamukti & 3 & 45.8 & Perikanan, Pariwisata, Pertanian \\
\hline 7 & Ujungjaya & 3 & 87.8 & Peternakan, Pertanian, Perikanan, Pariwisata \\
\hline No & Kecamatan Cimanggu & Hierarki & Pra KS \% & Sektor Unggulan \\
\hline 1 & Cimanggu & 2 & 25.1 & Pertanian, Perkebunan \\
\hline 2 & Padasuka & 2 & 70.0 & Pertanian, Perkebunan, Peternakan \\
\hline 3 & Tugu & 2 & 63.3 & Perkebunan, Peternakan \\
\hline 4 & Waringinkurung & 2 & 45.9 & Pertanian, Perkebunan, Peternakan \\
\hline 5 & Cibadak & 3 & 77.8 & Pertanian, Perkebunan \\
\hline 6 & Mangkualam & 3 & 52.3 & Pertanian, Perkebunan \\
\hline 7 & Tangkilsari & 3 & 46.9 & Pertanian, Perkebunan \\
\hline 8 & Cijaralang & 3 & 80.7 & Pertanian, Perkebunan \\
\hline 9 & Batuhideung & 3 & 49.1 & Pertanian, Perkebunan, Peternakan \\
\hline 10 & Kramatjaya & 3 & 79.9 & Pertanian, Perkebunan \\
\hline 11 & Ciburial & 3 & 57.2 & Pertanian, Perkebunan, Peternakan \\
\hline 12 & Rancapinang & 3 & 84.4 & Pertanian, Perkebunan \\
\hline
\end{tabular}

\section{Arahan Strategi Pengembangan Wilayah di Kecamatan Sumur}

Berdasarkan analisis SWOT, strategi yang dipilih adalah strategi SO (Strengths-Opportunities) dengan subsektor perikanan dan pariwisata sebagai sektor unggulan. Subsektor perikanan dan pariwisata di Kecamatan Sumur berada pada sel 1, dan berada pada kuadran I. Strategi SO sebagai strategi utama yang dibuat dengan memanfaatkan kekuatan dan peluang bagi pengembangan produksi di Kecamatan Sumur.

\section{Arahan Strategi Pengembangan Wilayah di Kecamatan Cimanggu}

Berdasarkan analisis SWOT, strategi yang dipilih adalah strategi SO (Strengths-Opportunities) dengan subsektor pertanian dan perkebunan. Subsektor pertanian dan perkebunan di Kecamatan Cimanggu berada pada sel 1, dan kuadran I. Strategi SO sebagai strategi utama yang memanfaatkan kekuatan dan peluang bagi pengembangan produksi di Kecamatan Cimanggu. 


\begin{tabular}{|c|c|}
\hline EKSTERNAL & $\begin{array}{l}\text { KEKUATAN } \\
\text { 1. Sumberdaya perikanan dan pariwisata yang masih terjaga dan tersedia } \\
\text { 2. Sektor perikanan dan pariwisata merupakan sektor unggulan } \\
\text { 3. Sektor perikanan dan pariwisata sebagai kegiatan ekonomi dominan } \\
\text { masyarakat } \\
\text { 4. Kebijan RTRW Kecamatan Sumur untuk pengembangan pariwisata } \\
\text { 5. Posisi strategis Kec. Sumur sebagai gerbang akses keluar masuk wilayah, } \\
\text { baik darat maupun laut }\end{array}$ \\
\hline $\begin{array}{l}\text { PELUANG } \\
\text { 1. Pengembangan kegiatan ekonomi berbasis sektor perikanan, dan } \\
\text { pariwisata sebagai sektor unggulan } \\
\text { 2. Optimalisasi pengembangan sektor perikanan dapat diwujudkan } \\
\text { karena permintaan pasar pada komoditas perikanan cenderung } \\
\text { naik } \\
\text { 3. Produktivitas sektor perikanan dapat didorong dengan penerapan } \\
\text { teknologi perikanan modern } \\
\text { 4. Peningkatan kegiatan ekonomi masyarakat khusunya pada sektor } \\
\text { perikanan dan pariwisata dapat didorong dengan penyediaan } \\
\text { fasilitas, sarana dan prasarana penunjang kegiatan ekonomi }\end{array}$ & $\begin{array}{l}\text { Strategi SO (Kuadran I) } \\
\text { 1. Mendorong kegiatan ekonomi pada sektor perikanan dan pariwisata } \\
\text { 2. Mendorong optimalisasi sektor perikanan dengan memanfaatkan } \\
\text { permintaan pasar dengan strategi peningkatan produktivitas perikanan } \\
\text { melalui penerapan teknologi perikanan modern } \\
\text { 3. Mendorong pembangunan dan penyediaan fasilitas, sarana dan prasarana } \\
\text { penunjang kegiatan ekonomi } \\
\text { 4. Memanfaatkan posisi strategis Kecamatan Sumur dengan membangun } \\
\text { infrastruktutr khususnya akses transportasi laut dengan membangun } \\
\text { pelabuhan/darmaga yang lebih baik. }\end{array}$ \\
\hline
\end{tabular}

Gambar 2. Hasil analisis matriks SWOT di Kecamatan Sumur

\begin{tabular}{|l|l|}
\hline \multicolumn{1}{|c|}{ INTERNAL } & $\begin{array}{l}\text { KEKUATAN } \\
\text { 1. Sektor pertanian, perkebunan dan peternakan sebagai sektor unggulan } \\
\text { 2. Sektor pertanian, perkebunan dan peternakan sebagai kegiatan } \\
\text { ekonomi dominan masyarakat. } \\
\text { 3. Lahan pertanian masih tersedia }\end{array}$ \\
\hline $\begin{array}{l}\text { PELUANG } \\
\text { 1. Pengembangan kegiatan ekonomi masyarkat pada sektor } \\
\text { pertanian, perkebunan dan peternakan sebagai unggulan. } \\
\begin{array}{l}\text { 2. Pengembangan sektor pertanian, perkebunan dan } \\
\text { peternakan yang lebih optimal. }\end{array}\end{array}$ & $\begin{array}{l}\text { Strategi SO (Kuadran I) } \\
\text { 1. Mendorong kegiatan ekonomi masyarakat berbasis pada sektor } \\
\text { pertanian, perkebunan dan peternakan sebagai sektor unggulan } \\
\text { 2. Mendorong optimalisasi subsektor pertanian dan perkebunan sebagai } \\
\text { kegiatan ekonomi masyarakat dengan penerapan teknologi pertanian, } \\
\text { perkebunan dan peternakan }\end{array}$ \\
\hline
\end{tabular}

Gambar 3. Hasil analisis matriks SWOT di Kecamatan Cimanggu

\section{Arahan Program Pengembangan Wilayah}

Arahan program pengembangan wilayah diprioritaskan kepada pembangunan ekonomi masyarakat yang dititikberatkan pada pembangunan subsektor pertanian, perkebunan, perikanan dan pariwisata serta mendorong keseimbangan pembangunan ke arah sektor perdagangan dan jasa seperti disajikan pada Gambar 4 dan Tabel 6.

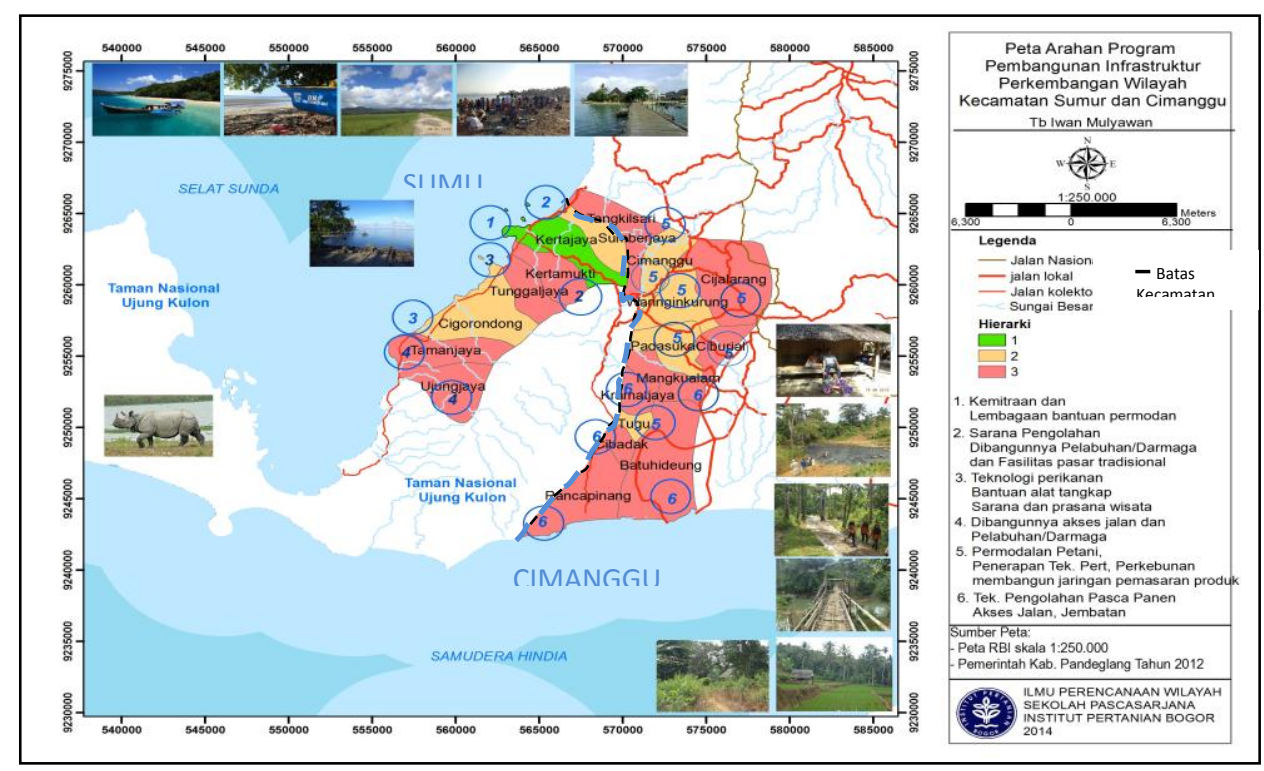

Gambar 4. Arahan program pengembangan wilayah 
Pada Gambar 4, tampak bahwa posisi wilayah desadesa di Kecamatan Sumur berada di kawasan pesisir, sedangkan desa-desa di Kecamatan Cimanggu berada di dataran yang lebih tinggi. Kondisi ini menggambarkan kedua kecamatan memiliki potensi yang berbeda. Arahan program pengembangan wilayah desa di Kecamatan Sumur di pusatkan pada sektor perikanan, pariwisata, pertanian, dan peternakan. Posisi wilayah yang berada di kawasan pesisir menjadi potensial untuk pengembangan sektor perikanan dan pariwisata, sementara pengembangan sektor pertanian dan peternakan dapat memanfaatkan lahan-lahan terbuka yang belum termanfaatkan secara optimal. Arahan program pengembangan wilayah desa di Kecamatan Cimanggu dipusatkan pada sektor pertanian, peternakan, dan perkebunan. Dari aspek posisi wilayah dan potensi perekonomian menunjukkan bahwa di wilayah ini memang strategis dikembangkan ketiga sektor tersebut.

Tabel 6. Arahan program untuk pengembangan wilayah

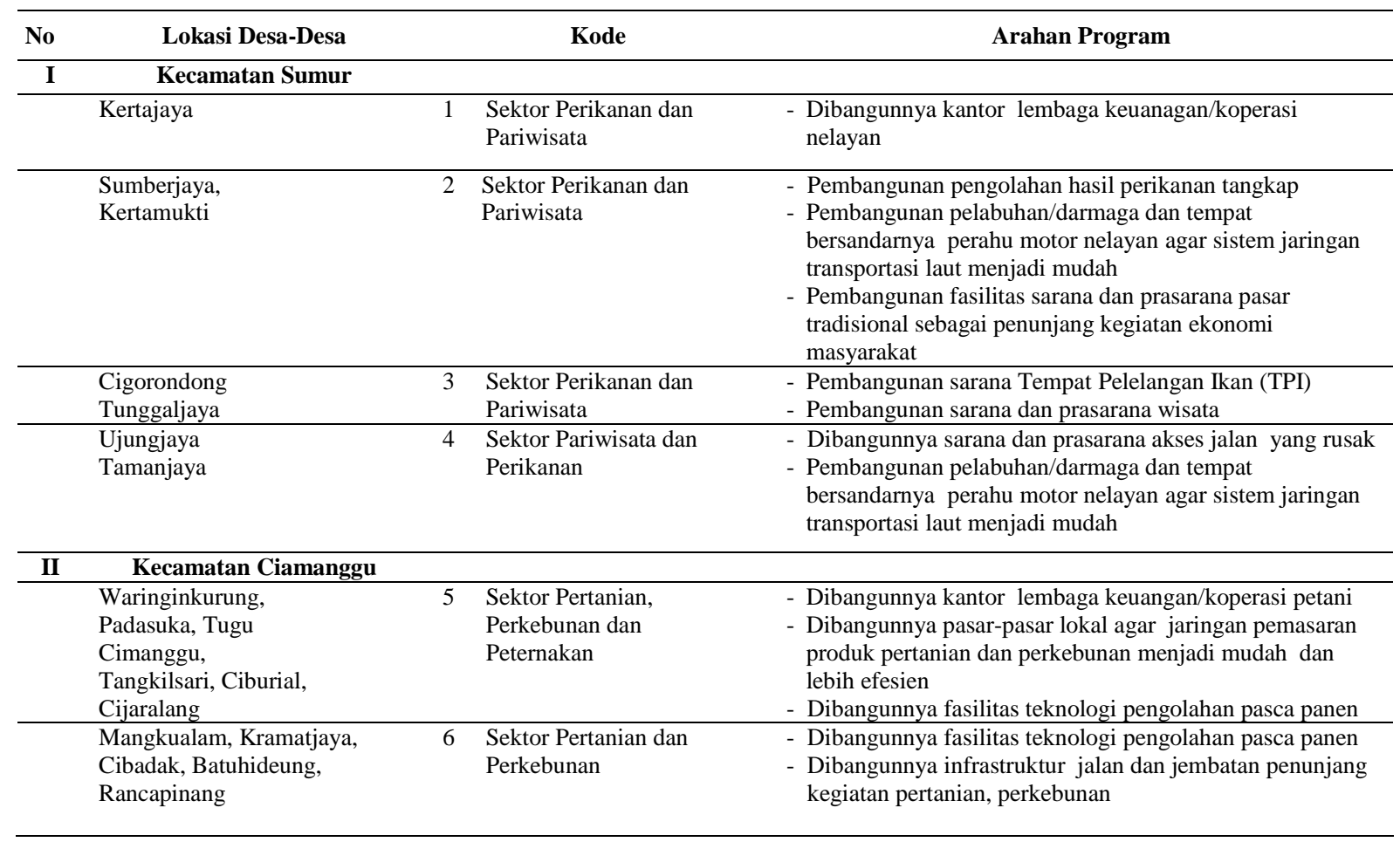

\section{SIMPULAN}

1. Analisis hierarki wilayah menunjukkan bahwa desadesa penyangga TNUK sebagian besar (12 Desa) termasuk dalam desa hierarki III dengan ketersediaan infrastruktur kurang. Ada 6 Desa yang termasuk hierarki II dengan ketersediaan infrastruktur sedang, sedangkan satu desa berada pada Hierarki I dengan ketersediaan infrastruktur baik

2. Sektor unggulan di desa-desa Kecamatan Sumur adalah pertanian, perikanan dan pariwisata. Sektor unggulan di desa-desa Kecamatan Cimanggu adalah pertanian, perkebunan dan peternakan

3. Arahan pengembangan wilayah di masa datang, desadesa di Kecamatan Sumur dapat dikembangkan sebagai pusat wilayah dengan perekonomian perikanan dan pariwisata, sedangkan desa-desa di Kecamatan Cimanggu dikembangkan sebagai pertanian dan perkebunan. Dengan pengembangan perekonomian tersebut diharapkan dapat mendorong peningkatan ekonomi masyarakat.

\section{DAFTAR PUSTAKA}

[BPS] Badan Pusat Statistik Kabupaten Pandeglang. Pandeglang Dalam Angka 2011. Kabupaten Pandeglang.

[BTNUK] Balai Taman Nasional Ujung Kulon. 2010. Penetapan zonasi di taman nasional ujung kulon. Laporan. Kementerian Kehutanan.

[BTNUK] Balai Taman Nasional Ujung Kulon. 2010. Sosialisasi potensi ekonomi sumberdaya air bersih di Gunung Honje. Taman Nasional Ujung Kulon. Laporan. Kementerian Kehutanan.

[Perda] Peraturan Daerah Provinsi Banten. 2011. Tentang Rencana Tata Ruang Wilayah Provinsi Banten No. 2 tahun 2010-2030. Provinsi Banten.

Niu X., B. Wang., S. Liu., C. Liu, W. Wei, and P.E. Kauppi. 2012. Economical assessment of forest ecosystem services in China: Characteristics and implications. Ecologycal Complexcity, 11: 1-11. 
Panuju, D.R. dan E. Rustiadi. 2011. Teknik Analisis Perencanaan Pengembangan Wilayah. Bagian Perencanaan Pengembangan Wilayah IPB. Bogor.

Rangkuti, F. 2009. Analisis SWOT Teknik Membedah Kasus Bisnis. PT. Gramedia Pustaka Utama. Jakarta.
Regameya, A. and S. Kytzia. 2007. Integrating the valuation of ecosystem services into the InputOutput economics of an Alpine Region. Ecologic Economics, 63: 786-798. 